\title{
Analysis of spironolactone polymorphs in active pharmaceutical ingredients and their effect on tablet dissolution profiles
}

\author{
Renata Cunha de Resende ${ }^{1}$, Olímpia Maria Martins Santos Viana ${ }^{1}$, Jennifer Tavares Jacon Freitas ${ }^{1}$, \\ Rudy Bonfilio", André Luís Morais Ruela ${ }^{2, *}$, Magali Benjamim de Araújo ${ }^{1}$
}

\begin{abstract}
${ }^{1}$ Department of Pharmacy, Faculty of Pharmaceutical Sciences, Federal University of Alfenas, Alfenas, MG, Brazil, ${ }^{2}$ Multidisciplinary Health Institute, Federal University of Bahia, Vitória da Conquista, BA, Brazil
\end{abstract}

\begin{abstract}
Spironolactone (SPR) is a steroidal drug administered as a potassium-sparing diuretic for high blood pressure treatment. The drug shows incomplete gastrointestinal absorption due to its poor aqueous solubility. The physicochemical properties of SPR in crystal forms I and II suggest that differences in their aqueous solubility may lead to a lack of bioequivalence between solid-state formulations. In this study, SPR polymorphs in five batches of active pharmaceutical ingredients (APIs) from three manufacturers were characterized using powder X-ray diffraction, infrared spectroscopy, thermal analysis, and solubility measurements. SPR tablets $(50 \mathrm{mg})$ were manufactured in our laboratory using API in pure form II, and API in form II contaminated with form I, which was found in a commercial batch. Physicochemical quality evaluations of the manufactured tablets, along with five SPR tablets marketed in Brazil, were performed, and results indicated differences in their dissolution profiles. In the manufactured tablets, differences were associated with the increased solubility of API in form II contaminated with form I compared to API in pure form II. In the marketed SPR tablets, the formulation composition demonstrated an important role in the dissolution rate of the drug, leading to lack of pharmaceutical equivalence among the drug products.
\end{abstract}

Uniterms: Spironolactone/dissolution profile. Spironolactone/pharmaceutical equivalence. Spironolactone/solubility. Spironolactone/polymorphism. Drugs/quality assessment.

\section{INTRODUCTION}

Spironolactone [SPR; $7 \alpha$-acetylthio-17 $\alpha$-hydroxyl3-oxopregn-4-ene-21-carboxylic acid $\gamma$-lactone], classified as a potassium-sparing diuretic, is a steroidal drug administered for the treatment of various disorders including high blood pressure, refractory edema in congestive heart failure, ascites, and essential hypertension (Giron, 1995; Soliman et al., 1997; Ismail, Chandrasekhar, Gunasekaran et al., 2014; Rahul, Patel, Bapna, 2014; Pisegna, Gilson, Butler, 2014; Zhang et al., 2014). The drug has also been administered for the treatment and prevention of hypokalemia (Rahul, Patel, Bapna, 2014), and reportedly has anti-androgenic activity, acting as a competitor for $5 \alpha$-dihydrotestosterone receptors (Ram, Dave, Joshi, 2012). According to its chemical structure (Figure 1), spironolactone is a lipophilic drug

*Correspondence: A. L. M. Ruela. Departamento de Alimentos e Medicamentos. Faculdade de Ciências Farmacêuticas. Universidade Federal de Alfenas. Rua Gabriel Monteiro da Silva, 700, 37130-000 - Alfenas - MG, Brasil. E-mail: andre.ruela@yahoo.com.br $\left(\log \mathrm{K}_{\mathrm{ow}}=2.78\right)$ with two ionizable groups $(\mathrm{pKa}=-4.9$ and 18.0 , respectively). It has been shown to be a crystalline powder, practically insoluble in water; however, it is soluble in alcohol and ethyl acetate, very soluble in chloroform and benzene, and slightly soluble in methanol (Brandão et al., 2008; Zhang et al., 2014).

The gastrointestinal absorption of SPR is variable and incomplete due to its poor water solubility (Agafonov et al., 1991; Liebenberg et al., 2003). It is classified as a class II drug according to the Biopharmaceutics Classification System (BCS) (Takahashi et al., 2012), which may be related to different arrays in the solid state due to its molecular flexibility (Salole, Al-Sarraj, 1985a; Salole, Al-Sarraj, 1985b; Berbenni et al., 1999; Liebenberg et al., 2003).

Polymorphisms of pharmaceutical solids can modify their physicochemical properties (Vippagunta, Brittain, Grant, 2001; Grant, Byrn, 2004; Detoisien et al., 2011). When a pharmaceutical solid exists in more than one form or crystal structure, significant differences in drug solubility may be detected, particularly for drugs that 


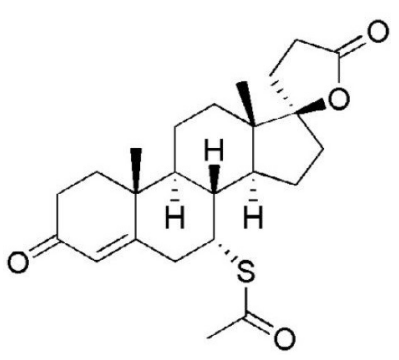

FIGURE 1 - Chemical structure of spironolactone $\left(\mathrm{C}_{24 \mathrm{H} 32 \mathrm{O} 4 \mathrm{~S}}\right)$. Molecular weight: $416.58 \mathrm{~g} \mathrm{~mol}^{-1}$.

are poorly water-soluble and classified as class II and IV according to the BCS (FDA, 2007; Bonfilio et al., 2014). In these cases, the dissolution step is the limiting step for drug absorption, and the lack of bioequivalence among different formulations may be related to polymorphisms (Amidon et al., 1995; Bauer et al., 2001; Desiraju, 2008; Aaltonen et al., 2009; Babu, Nangia, 2011; Santos et al., 2014; Atici, Karliga, 2015).

The aim of this study was to characterize the polymorphisms of different active pharmaceutical ingredients (APIs) of SPR obtained from different manufacturers. The effect of SPR crystal structure was also studied by performing physicochemical quality evaluations of tablets manufactured in our laboratory using API in pure form II, and API in form II contaminated with form I. Tablets commercially available in Brazil from different manufacturers were also evaluated.

\section{MATERIAL AND METHODS}

\section{Samples, chemicals, and reagents}

All reagents were of analytical grade, and were supplied by Núcleo de Controle de Qualidade da Faculdade de Ciências Farmacêuticas da Universidade Federal de Alfenas-MG (NCQ/FCF-UNIFAL-MG). The chemical reference substance (CRS) was a secondary standard validated in our laboratory, and designated as SPR-pd $2^{\circ}$ NCQ (Assay of $102.4 \%$, from Galena ${ }^{\circledR}$, Campinas, São Paulo, Brazil). Five batches of APIs of SPR from three manufacturers were selected for analysis; these were designated as SPR-L1 to SPR-L5. The excipients (starch, microcrystalline cellulose, magnesium stearate, lactose hydrous, and colloidal silicon dioxide) were purchased from local drugstores.

Spironolactone tablets $(50 \mathrm{mg})$ commercially available in Brazil from three manufacturers were also analyzed. The reference drug product in Brazil (Aldactone ${ }^{\circledR}$ $50 \mathrm{mg}$ manufactured by Pfizer ${ }^{\mathrm{TM}}$ ) was denominated as SPR-R. Three batches of tablets approved by the National
Health Surveillance Agency (Anvisa) as generic equivalent products were analyzed, and they were designated as SPR-G1 (manufacturer 1), SPR-G2 (manufacturer 2), and SPR-G3 (manufacturer 3). A non-approved batch by Anvisa, as a generic equivalent product, and also commercialized by manufacturer 1 , was also analyzed (SPR-S).

\section{HPLC analysis}

Samples of APIs and tablets were analyzed using an HPLC system from Shimadzu (Kyoto, Japan). Analyses were carried out using a validated method according to United States Pharmacopeia (USP, 2015), and used a $\mathrm{C}_{18}$ end-capping column [150.0 x $4.6 \mathrm{~mm}$ (i.d.)] with a $5 \mu \mathrm{m}$ particle size (Agilent Technologies ${ }^{\circledR}$, Santa Clara, CA, USA) at $25^{\circ} \mathrm{C}$. The mobile phase was a mixture of methanol and water $(60: 40, \mathrm{v} / \mathrm{v})$. The flow rate of the mobile phase was $1.0 \mathrm{~mL} \mathrm{~min}^{-1}$, injection volume was $50 \mu \mathrm{L}$, and UV detection was carried out at $230 \mathrm{~nm}$. Standard solutions at different SPR concentrations $(10,20$, $\left.40,60,80,100 \mu \mathrm{g} \mathrm{mL}^{-1}\right)$ were diluted in acetonitrile:water $(1: 1, \mathrm{v} / \mathrm{v})$ and analyzed $(n=3)$. The calibration equation and correlation coefficient $(r)$ were $y=46719 x+9188.3$ and 0.99975 , respectively. The samples were filtered using a $0.45 \mu \mathrm{m}$ syringe filter composed by hydrophilic PTFE. The retention time of SPR was approximately $9.7 \mathrm{~min}$. The total run time was $12.0 \mathrm{~min}$.

\section{Characterization of APIs}

\section{Powder X-ray diffraction (PXRD)}

Measurements of APIs by PXRD (PXRD, Ultima IV model, Rigaku ${ }^{\circledR}$, Tokyo, Japan) were carried out at room temperature under the following conditions: graphite monochromated $\mathrm{Cu}-\mathrm{K} \alpha$ radiation $(\lambda=1.54187$ $\AA$ ), voltage of $40 \mathrm{kV}$, current of $30 \mathrm{~mA}$, and rate scan of $1 \%$ min between 3 and $40^{\circ}$ of the $2 \theta$ range. The analysis was performed in order to characterize crystal structures present in the APIs.

\section{Thermal analysis}

Differential scanning calorimetry (DSC) was performed using a Netzsch-Gerätebau GmbH instrument model DSC 3500 Sirius (Selb, Germany). DSC thermograms of SPR were obtained at a heating rate of $10^{\circ} \mathrm{C} \mathrm{min}^{-1}$, from $30{ }^{\circ} \mathrm{C}$ to $240{ }^{\circ} \mathrm{C}$, under a $\mathrm{N}_{2}$ purge of $50 \mathrm{~mL} \mathrm{~min}^{-1}(n=3)$. Thermogravimetric analysis (TGA) was performed using an Exstar TG/DTA-7300 thermogravimetric analyzer (Chiba, Japan). TGA thermograms were obtained at a heating rate of $10{ }^{\circ} \mathrm{C} \mathrm{min}-1$, from $40{ }^{\circ} \mathrm{C}$ to $400{ }^{\circ} \mathrm{C}$, under a $\mathrm{N}_{2}$ purge of $50 \mathrm{~mL} \mathrm{~min}^{-1}$. 
Fourier transformed infrared spectroscopy with attenuated total reflection

Infrared analysis of the samples was performed using a Fourier transform infrared (FTIR) spectrometer, Shimadzu model Prestige 21 (Kyoto, Japan). An attenuated total reflectance (ATR) sampling accessory (model GladiATR 300, Pike Technologies, USA) was used, and the spectra were collected with no further processing of the samples.

\section{Solubility}

Solubility measurements were performed by a shaking-flask method at $25^{\circ} \mathrm{C}$. An excess of API was added to each medium $(5 \mathrm{~mL})$ and shaken $(150 \mathrm{rpm})$ for $48 \mathrm{~h}(n=3)$. The supernatant was taken, filtered using a $0.45 \mu \mathrm{m}$ syringe filter composed by hydrophilic PTFE, diluted in mobile phase $(1: 1, \mathrm{v} / \mathrm{v})$, and analyzed by HPLC.

The following media were evaluated: water; $0.01 \mathrm{~mol} \mathrm{~L}^{-1}$ chloride acid ( $\left.\mathrm{HCl}\right) ; 0.1 \mathrm{~mol} \mathrm{~L}^{-1} \mathrm{HCl}$; $0.1 \mathrm{~mol} \mathrm{~L}^{-1} \mathrm{HCl}+0.1 \%(\mathrm{w} / \mathrm{v})$ sodium dodecyl sulfate; $0.1 \mathrm{~mol} \mathrm{~L}^{-1}$ sodium citrate buffer $(\mathrm{pH} 3.0) ; 0.1 \mathrm{~mol} \mathrm{~L}^{-1}$ sodium acetate buffer ( $\mathrm{pH} 4.5) ; 0.1 \mathrm{~mol} \mathrm{~L}^{-1}$ potassium phosphate buffer ( $\mathrm{pH} \mathrm{6.2)}$; and $0.1 \mathrm{~mol} \mathrm{~L}^{-1}$ potassium phosphate buffer ( $\mathrm{pH}$ 7.2).

\section{Preparation of SPR tablets}

To evaluate the influence of polymorphisms in spironolactone tablets $(50 \mathrm{mg})$, two batches were prepared; batch A (containing SPR-L1 in polymorphic form II, but with contamination by polymorphic form I) and batch B (containing SPR-L2 in polymorphic form II without contamination). The particles of SPR APIs were previously sieved $(48-60 \mu \mathrm{m})$. The two batches were prepared in a similar manner by direct compression using a single rotary tablet compression machine. A placebo mixture was prepared based on the qualitative composition of reference drug product by weighing out the following ingredients: starch $(6.5 \%)$, microcrystalline cellulose $(77.0 \%)$, magnesium stearate $(1.0 \%)$, lactose hydrous $(15 \%)$, and colloidal silicon dioxide $(0.5 \%)$. These excipients were mixed with API (batch A or batch B), and the mixture was compressed. The average weight ( \pm relative standard deviation, RSD) and hardness of the manufactured SPR tablets were adjusted according to the data obtained from physical tests with the SPR-R.

\section{Physicochemical quality evaluation of APIs and tablets}

Assay

Assays of APIs and tablets were performed according to the specifications of USP (2015). Samples were diluted in mobile phase at a drug concentration of $40.0 \mu \mathrm{g} \mathrm{mL}^{-1}(n$ $=5$ ), and analyzed by HPLC.

\section{Content uniformity of the manufactured SPR tablets}

Evaluation of the homogeneity of the manufactured tablets (batch A and batch B) was performed according to the specifications of USP 38-NF 33 (2015). Samples at a final concentration of $50.0 \mu \mathrm{g} \mathrm{mL}^{-1}$ diluted in mobile phase were prepared $(n=10)$ and analyzed by HPLC.

\section{Evaluation of the dissolution profiles}

Evaluation of the dissolution profiles of the tablets ( $n$ $=6$ ) was performed in a Electrolab ${ }^{\mathrm{TM}}$ TDT- 08 L multi bath ( $n$ $=8$ ) dissolution test system (Mumbai, Maharashtra, India). The following conditions were used: USP II apparatus (paddle) at $75 \mathrm{rpm}$ and $1000 \mathrm{~mL}$ of $0.1 \mathrm{~mol} \mathrm{~L}^{-1} \mathrm{HCl}+$ $0.1 \%$ sodium dodecyl sulfate at $37.0 \pm 0.5^{\circ} \mathrm{C}$. Samples were withdrawn $(10 \mathrm{~mL})$ at different times $(5,10,15$, $30,45,60$, and $90 \mathrm{~min}$ ), filtered using quantitative paper filter, and diluted with dissolution medium $(1: 1, \mathrm{v} / \mathrm{v})$. The quantification of SPR in dissolution medium was performed by UV spectrophotometry $(\lambda=242 \mathrm{~nm})$ using a Shimadzu ${ }^{\circledR}$ spectrophotometer, model UV-1800 PC (Kyoto, Japan).

The dissolution profiles of the SPR tablets marketed in Brazil were compared by calculating the dissolution efficacy $\left(\mathrm{DE}_{0-90} \%\right)$ as the percentage of the area under the release curve between 0 and 90 min (Anderson et al., 1998; Serra, Storpirtis, 2007).

The dissolution profiles of tablets manufactured in our laboratory, batch A and batch B, were compared using the model-independent mathematical approach by calculating the factor $\mathrm{f} 2$ :

$$
f 2=50 \times \log \left\{\left[1+\left(\frac{1}{n}\right) \sum_{t=1}^{n}(R t-T t)^{2}\right]^{-0.5} \times 100\right\}
$$

where, $n$ is the number of selected time points; $R t$ is the cumulative percentage dissolved at each of the selected $n$ time points of the reference product; and $T t$ is the cumulative percentage dissolved at each of the selected $n$ time points of the test product. The factor $\mathrm{f} 2$ measures the closeness between the two dissolution profiles, and a value between 50 and 100 indicates similarity of the two profiles (Farmacopeia, 2010; FDA, 2014).

\section{Statistical analysis}

Samples were compared using 1-way analysis of variance (ANOVA). In all cases, post hoc comparisons 


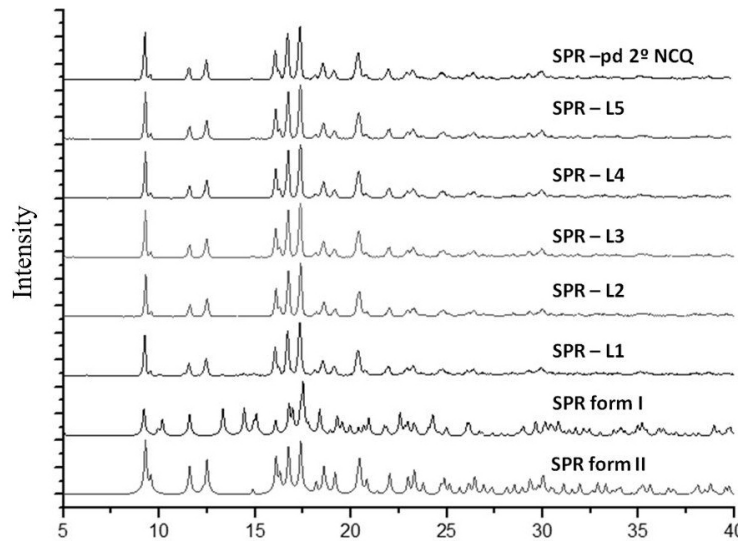

A)

$2 \theta\left({ }^{\circ} \mathrm{C}\right)$

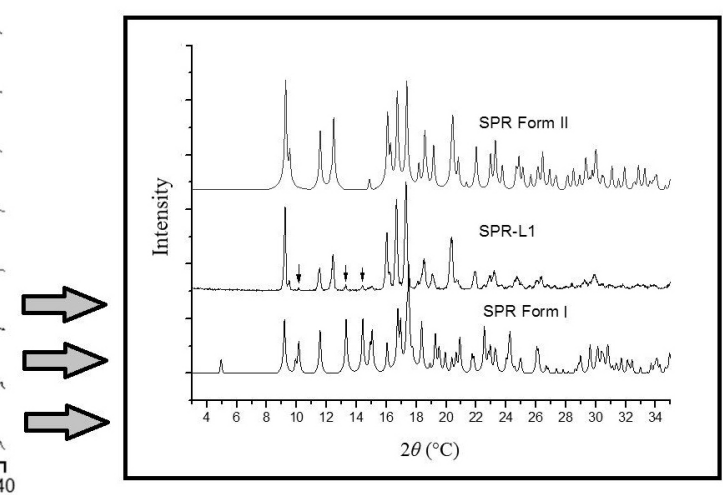

B)

FIGURE 2 - PXPD of spironolactone in active pharmaceutical ingredients: A) SPR-L1 to SPR-L5 in comparison with the simulated PXPD of forms I and II; B) Characterization of form II contaminated with form I in SPR-L1.

of the means for individual groups were performed using Tukey's test. $P$ values of $<0.05$ were considered statistically significant.

\section{RESULTS AND DISCUSSION}

\section{Characterization of active pharmaceutical ingredients}

The identification of crystal structures in APIs in the solid state was determined using PXRD. The diffraction pattern is related to the packing of the crystal structure and its array in the solid state (Bonfilio et al., 2014). To determine the occurrence of polymorphisms in APIs of SPR, diffractograms (SPR-L1 to L5, and SPR-pd ${ }^{\circ}$ NCQ) were compared to data available from the Cambridge Structural Database (CSD) for crystal form I (Dideberg; Dupont, 1972) and crystal form II (Agafonov, Legendre, Rodier, 1989). These data are shown in Figure 2A.

These results indicate the occurrence of pure form II in samples SPR-L2, SPR-L3, SPR-L4, SPR-L5, and SPR-R (Figure 2B). Peaks at 10.1, 13.2, 14.6, and $15.2^{\circ} 2 \theta$ were observed in SPR-L1, and related to a contamination with form I, characterizing this API as a mixture of both forms I and II. Similar results were observed by Liebenberg and coworkers (2003) during the evaluation of five different SPR APIs using PXRD, in which they characterized one batch of API as a mixture of crystal forms I and II. In general, SPR is used in the pharmaceutical industry in form II due to its higher stability (Nicolai et al., 2007; Zhang et al., 2014). However, these results indicate that SPR APIs from different manufacturers may be contaminated with other crystal structures, leading to problems in formulation performance.

The characterization of the APIs SPR-pd $2^{\circ}$ NCQ (pure form II), SPR-L1 (pure form II), and SPR-L2 (form II contaminated with form I) was also performed by thermal analysis (DSC and TGA) in order to determine melting point and thermal stability. The melting point of SPR-pd $2^{\circ} \mathrm{NCQ}$ (Figure $3 \mathrm{~A}$ ) was $209.1^{\circ} \mathrm{C}\left(T_{\text {onset }}=203.0^{\circ} \mathrm{C}\right)$, and drug decomposition from $250^{\circ} \mathrm{C}$. These results are similar to those described for crystal form II (Agafonov et al., 1991; Espeau et al., 2007).

DSC thermograms of SPR-L1 and SPR-L2 (Figure 3B) showed melting points of $207.0^{\circ} \mathrm{C}(\mathrm{m}=5.62 \mathrm{mg} /$ DPR: $\left.0.05 \% / \mathrm{T}_{\text {onset }}: 197.3{ }^{\circ} \mathrm{C} / \Delta \mathrm{H}_{\text {fus }}=43.6 \mathrm{~mJ} \mathrm{mg}^{-1}\right)$ and $209.2{ }^{\circ} \mathrm{C}\left(\mathrm{m}=5.63 \mathrm{mg} / \mathrm{DPR}: 0.09 \% / \mathrm{T}_{\text {onset }}: 202.7{ }^{\circ} \mathrm{C} /\right.$ $\left.\Delta \mathrm{H}_{\text {fus }}=45.2 \mathrm{~mJ} \mathrm{mg}^{-1}\right)$, respectively. These results are similar those described by Liebenberg and coworkers (2003), in which the melting point of SPR API in pure form II $\left(204^{\circ} \mathrm{C}\right)$ was slightly lower compared to form II contaminated with form I $\left(205-206^{\circ} \mathrm{C}\right)$. Form II has a higher thermodynamic stability than form I, observed by its enthalpy of fusion (Agafonov et al., 1989; Agafonov et al., 1991; Liebenberg et al., 2003, Espeau et al., 2007). Drug decomposition was observed from $250{ }^{\circ} \mathrm{C}$ by TGA thermograms (Figure 3C).

Infrared spectra of the APIs (SPR-pd $2^{\circ} \mathrm{NCQ}$, SPR-L1, and SPR-L2) are shown in Figure 4. Stretching vibrations of thioacetyl were observed at $1689 \mathrm{~cm}^{-1}$, with stretching of $\gamma$-lactone at $1766 \mathrm{~cm}^{-1}$. Carbonyl $(\mathrm{C}=\mathrm{O})$ stretching at $1668 \mathrm{~cm}^{-1}$ and the stretching vibration of the $\mathrm{C}=\mathrm{C}$ bond at $1615 \mathrm{~cm}^{-1}$ were also observed. Differences among the infrared spectra of the evaluated SPR APIs were not observed. According to Berbenni and coworkers (1999), the discrimination of SPR polymorphs using infrared spectroscopy is not a simple task, and PXRD is recommended for appropriate characterization of SPR crystal forms. 

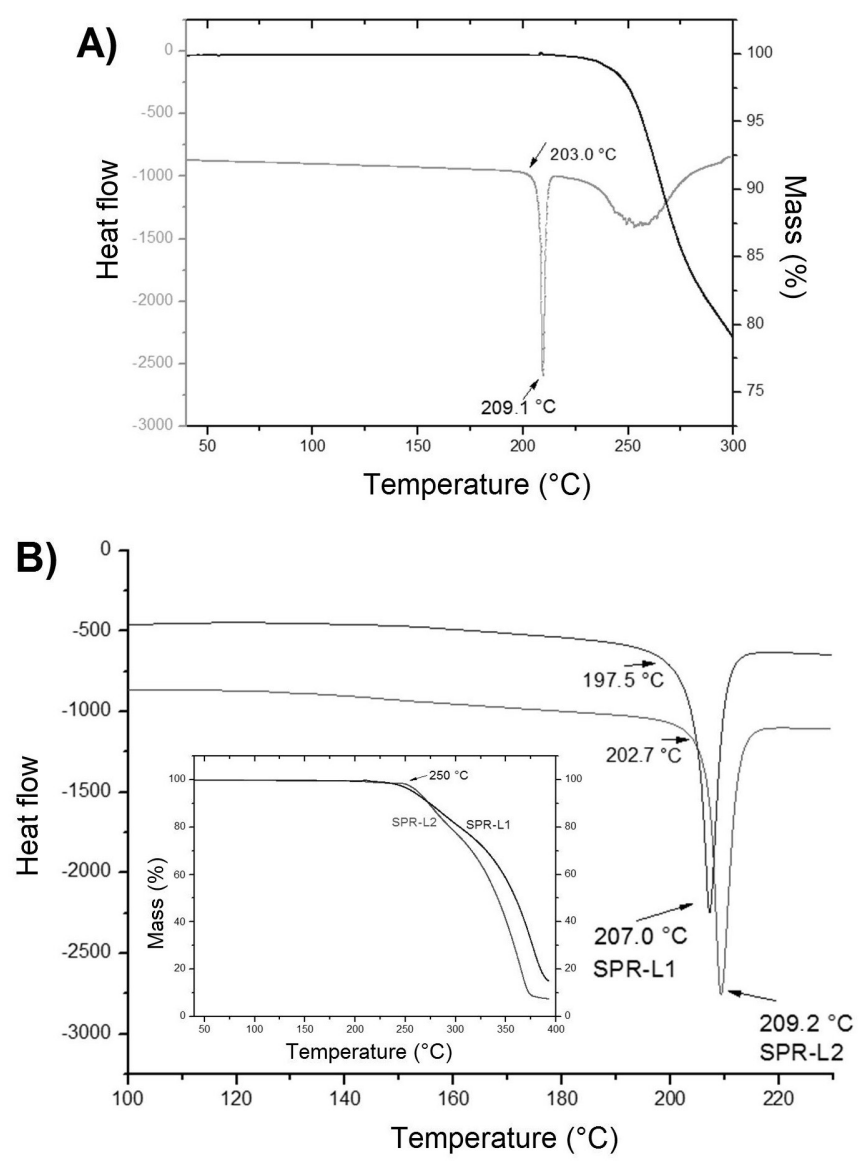

FIGURE 3 - A) DSC and TGA thermograms for the secondary reference standard (SPR-pd $2^{\circ} \mathrm{NCQ}$ ) of spironolactone in pure crystal form II; B) DSC and TGA thermograms of active pharmaceutical ingredients of spironolactone, SPR-L1 and SPR-L2, at a heating rate of $10{ }^{\circ} \mathrm{C} \mathrm{min}^{-1}$.

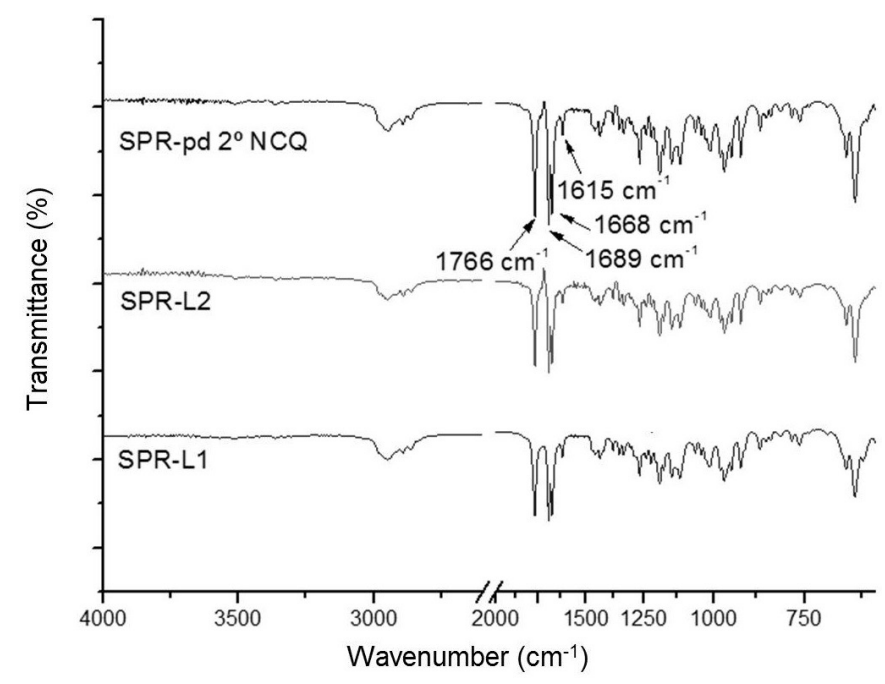

FIGURE 4 - Infrared spectra of active pharmaceutical ingredients (APIs) of spironolactone: Secondary reference standard (SPR-pd $2^{\circ} \mathrm{NCQ}$ ), and two different APIs (SPR-L1 and SPR-L2).
Assays of the APIs in SPR showed values of $99.90 \pm 0.43 \%$ for SPR-L 1 , and $99.30 \pm 0.89 \%$ for SPR-L2, according to the specifications in the API monograph (USP, 2015).

The solubility of SPR (Figure 5) form II was greater than that of form II contaminated with form I; this difference was seen in all aqueous media evaluated $(p<0.001)$. SPR solubility in $0.1 \mathrm{~mol} \mathrm{~L}^{-1} \mathrm{HCl}+0.1 \%(\mathrm{w} / \mathrm{v})$ sodium dodecyl sulfate was increased approximately 3 -fold compared to other aqueous media. The major difference between the solubility of SPR-L1 $\left(150.74 \pm 3.78 \mu \mathrm{g} \mathrm{mL}^{-1}\right)$ and SPR-L2 $\left(101.10 \pm 5.20 \mu \mathrm{g} \mathrm{mL}^{-1}\right)$ was observed in this medium $(p<0.01)$, confirming that SPR solubility in form II may be increased due to contamination by form I. The medium $0.1 \mathrm{~mol} \mathrm{~L}^{-1} \mathrm{HCl}+0.1 \%(\mathrm{w} / \mathrm{v})$ sodium dodecyl sulfate is recommended by USP (2015) to perform the dissolution test of SPR tablets. Sodium dodecyl sulfate is an anionic surfactant that improves the solubility of poorly watersoluble drugs due to the formation of a micellar solution (Ruela, De Araújo, Pereira, 2009). These results indicate that the in vivo performance of solid-state formulations containing different crystal structures of SPR may be modified, given that SPR is a poorly water-soluble drug and its dissolution is the limiting step for gastrointestinal absorption.

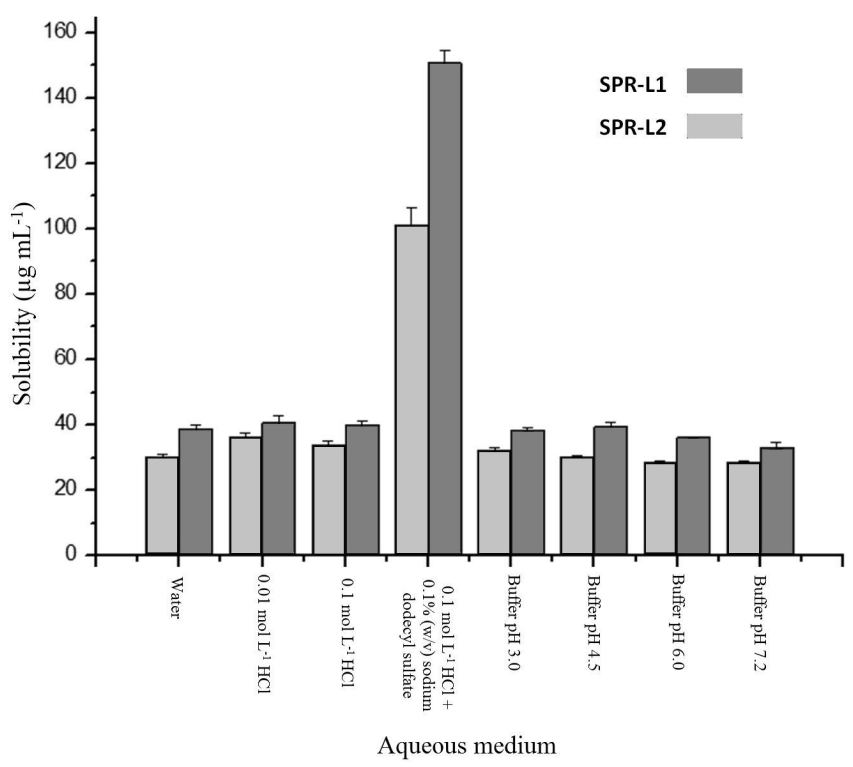

FIGURE 5 - Solubility of spironolactone $(n=3)$ at $25^{\circ} \mathrm{C}$ in aqueous media. The active pharmaceutical ingredients evaluated were SPR-L1, containing the crystal form II contaminated with form I, and SPR-L2, containing the pure form II.

\section{Evaluation of spironolactone tablets}

The average weight of SPR tablets manufactured 
in our laboratory was $413.2 \mathrm{mg}(\mathrm{RSD}=0.23 \%)$ for batch $\mathrm{A}$, and $409.5 \mathrm{mg}(\mathrm{RSD}=0.20 \%)$ for batch $\mathrm{B}$. These results are close to the average weight of the reference drug product $(409.2 \mathrm{mg}, \mathrm{RSD}=1.90 \%)$. The hardness of the SPR tablets was $11.4 \mathrm{kgf}$ for batch A, and $11.8 \mathrm{kgf}$ for batch $\mathrm{B}$, which is consistent with the hardness of the reference drug product (12.3 kgf). The content uniformity of the tablets were also determined $(n=10)$; results were $100.97 \pm 3.83 \%$ for SPR-R, $99.68 \pm 2.12 \%$ for batch A, and $99.39 \pm 0.83 \%$ for batch B.

\section{Dissolution profiles of manufactured spironolactone tablets}

The dissolution profiles of tablets from batch $\mathrm{A}$ and $\mathrm{B}$ are shown in Figure 6A. The amount of drug dissolved at $60 \mathrm{~min}$ was $89.32 \pm 3.43 \%$ for batch $\mathrm{A}$, and $79.55 \pm 9.72 \%$ for batch B. However, comparison of the dissolution profiles using factor $\mathrm{f} 2$ indicates a value of 19.00. According to this result, dissolution profiles of the manufactured tablets were different, which may be related to the solubility of the APIs (SPR-L1 and SPR-L2). The dissolution rate of tablets in batch A was higher than those in batch $\mathrm{B}$, and may be due to the fact that tablets in batch A were manufactured with a more soluble API (SPR-L1). Considering that, these solid-state formulations were prepared with the same excipients and process, the effect of SPR polymorphisms in drug solubility and dissolution rates may alter the in vivo pharmacokinetics of this drug, resulting in a lack of bioequivalence among drug products.

\section{Dissolution profiles of spironolactone tablets marketed in Brazil}

The dissolution profiles of tablets commercially available in Brazil are shown in Figure 6B. SPR-R tablet was characterized as a rapidly dissolving drug product, given that $84.86 \pm 4.15 \%$ of the drug was released at 5 min. SPR-G2 and SPR-S tablets released more than $90 \%$ of the drug at $15 \mathrm{~min}$, and they were also characterized as rapidly dissolving drug products. The same manufacturer produces SPR-G2 and SPR-S drug products. SPR-G1 and SPR-G3 showed a slower dissolution rate than the other marketed drug products, achieving a dissolved drug amount $>75 \%$ at $30 \mathrm{~min}$. These results met the requirements of the monograph described by USP 38-NF 33 (2015) for SPR tablets (dissolution $>75 \%$ in $60 \mathrm{~min}$ ). However, these results clearly demonstrate the lack of pharmaceutical equivalence among some formulations. The factor $\mathrm{f} 2$ was not applied for comparison of the dissolution profiles due to the fast release from the reference drug product, SPR-R (FDA, 2014). In this case, the $\mathrm{DE}_{0-90} \%$ was calculated to compare dissolution profiles (Figure 7).

There were significant differences among the values of $\mathrm{DE}_{0-90} \%$ for the marketed SPR tablets $(p<0.001)$. The $\mathrm{DE}_{0-90} \%$ of the reference drug product (SPR-R) showed the highest value $(95.95 \pm 1.32 \%)$, characterizing the rapid and complete release of SPR in a short time. The other marketed drug products did not achieve the same $\mathrm{DE}_{0-90} \%$ as SPR-R. SPR-G1 and SPR-G3 showed the lowest values of $\mathrm{DE}_{0-90} \%$ at $77.38 \pm 3.24 \%$ and $73.24 \pm$ $3.53 \%$, respectively, and they were significantly different from SPR-G2 and SPR-S, which showed values of 89.52 $\pm 1.55 \%$ and $89.92 \pm 3.02 \%$, respectively. These results indicate the lack of pharmaceutical equivalence among the evaluated solid-state formulations. Therefore, formulation scientists must carefully explore the design of SPR formulations in order to optimize their performance, and improve pharmaceutical equivalence and bioequivalence among these drug products.
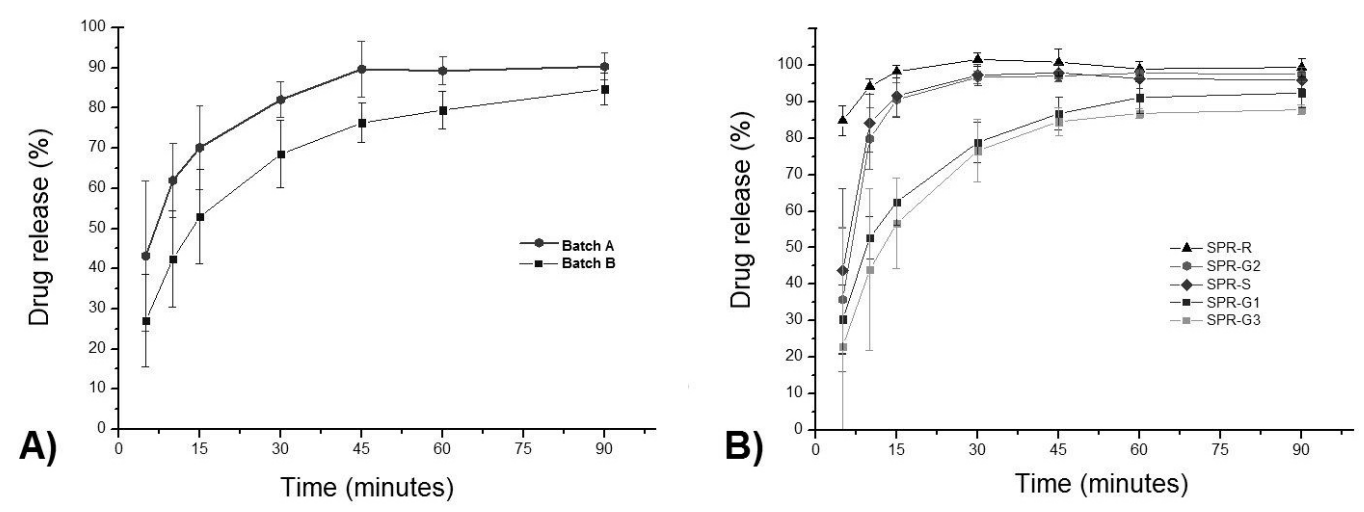

FIGURE 6 - A) Dissolution profiles of spironolactone tablets $(50 \mathrm{mg})$ in batch A and batch B $(n=6)$; B) Dissolution profiles of spironolactone tablets $(50 \mathrm{mg})$ marketed in Brazil $(n=6)$. 


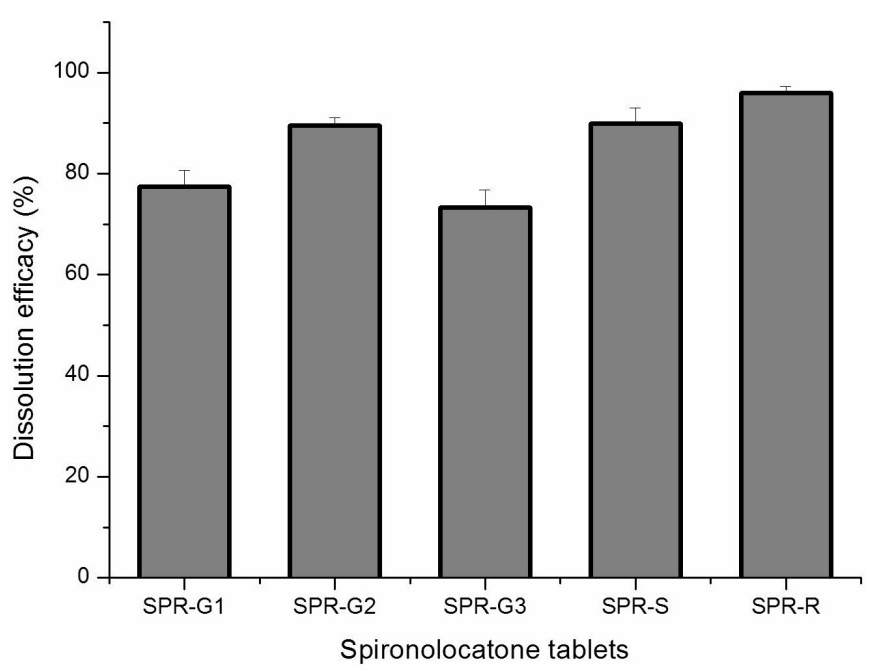

FIGURE 7 - Dissolution efficacy (\%) of marketed $50 \mathrm{mg}$ spironolactone tablets $(n=6)$.

\section{CONCLUSIONS}

The polymorphs of SPR in raw materials from different manufacturers were characterized as pure form II in four batches of this API, and one commercial batch containing form II contaminated with form I. The solubility measurements of these APIs indicated a higher solubility of form II contaminated with form I compared to the API in pure form II. Analysis of tablets manufactured with these APIs indicated that the presence of form I in the API leads to an increased dissolution rate, which was associated with the major solubility of this crystal structure. Different dissolution profiles were also characterized from SPR tablets marketed in Brazil, suggesting that formulation composition may modify the release rate of this poorly water-soluble drug. Collectively, these findings indicate the need for preformulation studies to characterize the polymorphs of SPR in APIs. In addition, formulation scientists must consider the impact of polymorphs in solidstate formulations, as well as that of the excipients, on the dissolution properties of these formulations.

\section{ACKNOWLEDGMENTS}

The authors are grateful for CAPES (Brasília, Brazil), CNPq (Brasília, Brazil), Fapemig (Belo Horizonte, Brazil) and the Pharmaceutical Equivalence Center of NCQ-FCF-Unifal-MG (Alfenas, Brazil) for research fellowships.

\section{REFERENCES}

AALTONEN, J.; ALLESO, M.; MIRZA, S.; KORADIA, V.; GORDON, K. G.; RANTANEN, J. Solid form screening - a review. Eur. J. Pharm. Biopharm., v.71, n.1, p.23-37, 2009.

AGAFONOV, V.; LEGENDRE, B.; RODIER, N.; WOUESSIDJEWE, D.; CENSE, J.M. Polymorphism of spironolactone. J. Pharm. Sci., v.80, n.2, p.181-5, 1991.

AGAFONOV, V.; LEGENDRE, B.; RODIER, N. A new crystalline modification of spironolactone. Acta Cryst., v.C45, p.1661-3, 1989.

AMIDON, G. L.; LENNERNAS, H.; SHAH, V.P.; CRISON, J.R. A theoretical basis for a biopharmaceutic drug classification: the correlation of in vitro drug product dissolution and in vivo bioavailability. Pharm. Res., v.12, n.13, p.413-20, 1995.

ANDERSON, N.H.; BAUER, M.; BOUSSAC, N.; KHANMALEK, R.; MUNDEN, P.; SARDARO, M. An evaluation of fit factors and dissolution efficiency for the comparison of in vitro dissolution profiles. J. Pharm. Biomed. Anal., v.17, n.4-5, p.811-22, 1998.

ATICI, E.B.; KARLIGA, B. Quantitative determination of two polymorphic forms of imatinib mesylate in a drug substance and tablet formulation by X-ray powder diffraction, differential scanning calorimetry and attenuated total reflectance Fourier transform infrared spectroscopy. $J$. Pharm. Biomed. Anal., v.114, p.330-40, 2015.

BABU, N.J.; NANGIA, A. Solubility advantage of amorphous drugs and pharmaceutical cocrystals. Cryst. Growth Des., v.11, n.7, p.2662-79, 2011.

BAUER, J.; SPANTON, S.; HENRY, R.; QUICK, J.; DZIKI, W.; PORTER, W.; MORRIS, J. Ritonavir: An extraordinary example of conformational polymorphism. Pharm. Res., v.18, n.6, p.859-66, 2001.

BERBENNI, V.; MARINI, A.; BRUNI, G.; MAGGIONI, A.; RICCARDI, R.; ORLANDI, A. Physico-chemical characterisation of different solid forms of spironolactone. Thermochim. Acta, v.340-41, p.117-29, 1999. 
BONFILIO, R.; LEAL, J.S.; SANTOS, O.M.; PEREIRA, G.R.; DORIGUETTO, A.C.; DE ARAÚJO, M.B. Analysis of chlorthalidone polymorphs in raw materials and tablets and the effect of forms I and II on the dissolution properties of drug products. J. Pharm. Biomed. Anal., v.88, p.562-70, 2014.

BRANDÃO, F.C.; TAGIARI, M.P.; SILVA, M.A.S.; BERTI, L.F.; STULZER, H.K. Physical-chemical characterization and quality control of spironolactone raw material samples. Pharm. Chem. J., v.42, n.6, p.368-76, 2008.

DESIRAJU, G.R. Polymorphism: the same and not quite the same. Cryst. Growth Des., v.8, n.1, p.3-5, 2008.

DETOISIEN, C.; ARNOUX, M.; TAULELLE, P.; COLSON, D.; KLEIN, J.P.; STÉPHANE, V. Thermal analysis: A further step in characterizing solid forms obtained by screening crystallization of an API. Int. J. Pharm., v.403, n.1-2, p.29-36, 2011.

DIDEBERG, O.; DUPONT, L. La structure crystalline et moléculaire de la spironolactone. Acta Cryst., v.B28, p.3014-22, 1972.

ESPEAU, P.; NICOLAI, B.; CEÓLIN, R.; PERRIN, M.A.; ZASKE, L.; GIOVANNINI, J.; LEVEILLER, F. Thermal behavior of orthorhombic polymorphs I and II of spironolactone. J. Therm. Anal. Calorim., v.90, n.2; p.341-2, 2007.

FARMACOPEIA Brasileira. 5.ed. Brasília: Agência Nacional de Vigilância Sanitária, 2010. v.2, 904 p.

FOOD AND DRUG ADMINISTRATION. FDA. Guidance for Industry - ANDAs: Bioavailability and Bioequivalence Studies Submitted in NDAs or INDs General Considerations. Silver Spring, MD: FDA, 2014. Available at: <http://www.fda.gov/downloads/drugs/ guidancecomplianceregulatoryinformation/guidances/ ucm389370.pdf $>$. Accessed on: Nov. 2015.

FOOD AND DRUG ADMINISTRATION. FDA. Guidance for Industry - ANDAs: Pharmaceutical Solid Polymorphism Chemistry, Manufacturing, and Controls Information. Silver Spring, MD: FDA, 2007. Available at: < http://www.fda.gov/ downloads/Drugs/GuidanceComplianceRegulatoryInforma tion/Guidances/ucm072866.pdf>. Accessed on: Apr. 2015.

GIRON, D. Thermal analysis and calorimetric methods in the characterisation of polymorphs and solvates. Thermochim. Acta, v.248, p.1-59, 1995.
GRANT, D.J.W.; BYRN, S.R. A timely re-examination on drug polymorphism in pharmaceutical development and regulation. Adv. Drug Deliver. Rev., v.56, n.3, p.237-9, 2004.

ISMAIL, Y.; CHANDRASEKHAR, K. B.; GUNASEKARAN, $\mathrm{V}$. A new stability indicating UPLC method development and validation for the simultaneous estimation of metolazone and spironolactone in bulk and in its pharmaceutical formulations. Int. J. Pharm. Pharma. Sci., v.6, n.10 p.448$52,2014$.

LIEBENBERG, W.; VAN TONDER, E.C.; DEKKER, T.G.; DE VILLIERS, M.M. Variable temperature X-Ray powder diffractometry of spironolactone polymorphs. Pharmazie, v. 58, n. 6, p. 435-7, 2003.

NICOLAI, B.; ESPEAU, P.; CÉOLIN, R.; PERRIN, M.A.; ZASKE, L.; GIOVANNINI, J.; LEVEILLER, F. Polymorph formation from solvate desolvation: Spironolactone forms I and II from the spironolactone-ethanol solvate. J. Thermal Anal. Calor., v.90, n.2, p.337-9, 2007.

PISEGNA, G. L.; GILSON, D. F.R.; BUTLER, I. S. Highpressure infrared and Raman studies of polymorphism in pharmaceutical compounds: Spironolactone, Forms I and II. J. Mol. Struct., v.1078, p.146-50, 2014.

RAHUL, C.R.; PATEL, J.; BAPNA, M. Development and validation of analytical method for estimation of Spironolactone in oral suspension. J. Chem. Biol. Phys. Sci., v.4, n.3 p.2196-204, 2014.

RAM, V.R.; DAVE, P.N.; JOSHI, H.S. Development and validation of a stability-indicating HPLC assay method for simultaneous determination of spironolactone and furosemide in tablet formulation. J. Chromatogr. Sci., v.50, n.8, p.721-6, 2012.

RUELA, A.L.M.; DE ARAÚJO, M. B.; PEREIRA, G.R. Desenvolvimento de um teste de dissolução para comprimidos de nimesulida em meio que assegure condições sink. Acta Farm. Bonaer., v.28, n.5, p.661-667, 2009.

SALOLE, E.J.; AL-SARRAJ, F.A. Effect of solvent-deposition on spironolactone crystal form. Drug Develop. Ind. Pharm., v.11, n.12, p.2061-70, 1985a.

SALOLE, E.G.; AL-SARRAJ, F.A. Spironolactone crystal forms. Drug Dev.Ind. Pharm., v.11, n.4, p.855-64, 1985 b. 
SANTOS, O.M.M.; REIS, M.E.D; JACON, J.T.; LINO, M.E.S.; SIMÕES, J.S.; DORIGUETTO, A.C. Polymorphism: an evaluation of the potential risk to the quality of drug products from the Farmácia Popular Rede Própria. Braz. J. Pharm. Sci., v.50, n.1, p.1-24, 2014.

SERRA, C.H.R.; STORPIRTIS, S. Comparação de perfis de dissolução da cefalexina através de estudos de cinética e eficiência de dissolução (ED\%). Ver. Bras. Ciênc. Farm., v.43, n.1, 2007.

SOLIMAN, O.A.E.; KIMURA, K.; HIRAYAMA, F.; UEKAMA, K.; EL-GAWAD, A.E.H.A.; HASHIM, F.M. Amorphous spironolactone-hydroxypropylated cyclodextrin complexes with superior dissolution and oral bioavailability. Int. J. Pharm., v.149, n.1, p.73-83, 1997.

TAKAHASHI, A. I.; LOURENÇO, F.R.; DUQUE, M.D.; CONSIGLIERI, V.O.; FERRAZ, H.G. Using fluid bed granulation to improve the dissolution of poorly watersoluble drugs. Braz. Arch. Biol. Technol., v.55, n.3, p.47784, 2012.
UNITED STATES PHARMACOPEIA. USP. 38 ed. National Formulary 33. Rockville: United States Pharmacopeial Convention, 2015.

VIPPAGUNTA, S.R.; BRITTAIN, H.G.; GRANT, D.J.W. Crystalline solids. Adv. Drug Deliver. Rev., v.48, n.1, p.326, 2001.

ZHANG, J.; WANG, Y.; WANG., G.; HAO, H.; WANG, H.; LUAN, Q.; JIANG, C. Determination and correlation of solubility of spironolactone form II in pure solvents and binary solvent mixtures. J. Chem. Thermodyn., v.79, p.618, 2014.

Received for publication on $22^{\text {th }}$ January 2016 Accepted for publication on $05^{\text {th }}$ September 2016 
